\title{
20. Gender and labour market outcomes
}

\author{
Anna Matysiak and Ewa Cukrowska-Torzewska
}

\section{PAST TRENDS AND CROSS-COUNTRY DIFFERENCES}

\subsection{Gender Gap in Employment and Working Hours}

All over Europe women are less likely to be employed than men. In 2018, 63.3 per cent of working age women in the European Union (EU) (EU-27 and United Kingdom (UK)) were in employment, which was 10.5 percentage points lower than for men (Eurostat 2020a). This difference was smallest in the Nordic countries, which since the 1970s have consistently been pursuing high women's employment, as well as Latvia and Lithuania (less than 5.6 percentage points). On the contrary, women were far less likely to be employed than men in Southern European countries (except for Portugal) and some of the post-socialist countries (Czech Republic, Hungary, Poland, Romania, and Slovakia). In most of the countries apart from the Czech Republic and Slovakia, the gender gap in employment is particularly large among the low or medium educated (Eurostat 2019a).

Historically, the gender gap in employment has been much wider. It slightly exceeded 30 percentage points in the early 1980 s and has been gradually narrowing since then (OECD 2019a, own calculations). This decline was particularly pronounced during the Great Recession, especially in countries where the economic situation deteriorated most strongly. This phenomenon was largely driven by a more severe destruction of jobs usually performed by men, i.e., in manufacturing and construction, than the typically female jobs in the service sector and by the increased effort of women to enter the labour market in response to a growing risk of income loss among their partners (Bettio et al. 2013). The downward trend in the size of the gender gap in employment has, however, stalled in the aftermath of the crisis and in some countries the disparities even started to grow again (e.g., in Spain or Ireland) (OECD 2017).

Women appear to be even less active in the labour market than men, if we consider that they work shorter hours. In 2018, women in the EU worked 34 hours per week on average, i.e., six hours less than men (Eurostat 2020b). This difference was particularly large in Austria, Germany, Ireland, the Netherlands, Switzerland and the UK, i.e., countries where part-time employment among women is most widespread. Part-time employment, however, is not a viable option in all countries. The opportunities to work part-time in Southern Europe and post-socialist countries of Central and Eastern Europe (CEE) are much more limited. Mothers in CEE are also reluctant to work part-time as it means lower earnings, which makes market work less attractive (Hobson et al. 2011; Kanjuo-Mrčela and Cernigoj Sadar 2011).

In contrast to women, men tend to work long hours (Adler and Lenz 2016; OECD 2017). The expectation for men to remain highly committed to work is still widespread in Europe, making it difficult for them to reduce work hours or make use of flexible work arrangements (Baranowska-Rataj and Matysiak forthcoming). Men work particularly long hours in countries where the regulations toward working time are either weak or weakly enforced (Mutari and Figart 2001). It is notable, however, that the Great Recession brought some reduction in men's 
working time, largely involuntary, and led to an increase in the part-time employment among men (Bettio et al. 2013).

\subsection{Gender-based Horizontal Segregation in Employment}

Women are not only less often present in employment than men, they also tend to cluster in certain sectors and occupations; a phenomenon termed as a gender-based horizontal segregation. In the EU, women predominate in services, mainly in sales and retail trade, health and social work, while men predominate in manufacturing and construction. Related to that, women and men also cluster in certain occupations. Women are more likely to work in clerical jobs, in services and sales and as professionals, while men are more likely to work as plant and machine operators, assemblers and craft and trade workers.

A common measure of the gender segregation in occupations is the 'Duncan and Duncan index of dissimilarity' (Duncan and Duncan 1955). It indicates what percentage of male/ female workers would have to change their jobs so that the proportion of men and women within occupations becomes equal. In the EU, this proportion was relatively stable over the last two decades and amounted to around 50 per cent $^{1}$ (Bettio and Verashchagina 2009; OECD 2017). There is, however, a huge cross-country variety of trends and levels behind this value. Historically, the gender occupational segregation was strongest in Nordic countries and lowest in Southern Europe, largely because an increase in female employment in the social-democratic welfare states went hand in hand with expansion of public services, which replaced the activities typically performed by women at home (Bettio 2002). With time, however, Nordic as well as some of the Western European countries and the United States (US) started to experience a desegregation. This process has been rather slow and is largely caused by a gradual increase in women's employment in typically male-dominated and neutral occupations rather than changes in the occupational structure of the economy (Bettio and Verashchagina 2009; Blau et al. 2013). At the same time, occupational segregation has been growing in Southern Europe and some of the post-socialist countries (Bettio and Verashchagina 2009), with the latter region currently displaying the highest segregation level in Europe (OECD 2017).

\section{Women and Men in Management}

Women are also underrepresented in managerial and supervisory positions; a phenomenon termed as vertical segregation. In 2018, the proportion of women among managers in the EU amounted to 34 per cent, though it varied across countries from above 40 per cent in Latvia, Poland, and Iceland to merely 17 per cent in Cyprus (Eurostat 2019b, own calculations). The representation of women in management has been increasing over time in almost all EU countries; yet the improvement was modest and amounted only to four percentage points over nearly 20 years (Eurostat 2019 b, own calculations). Women are particularly unlikely to be present at the chief executive level: in 2018 the proportion of female chief executive officers in publicly listed companies amounted to 6.3 per cent in the EU and 4.8 per cent in the US (ILO 2019). The low presence of women among managers has motivated some governments to implement strict gender quotas with penalties for non-compliance (Belgium, Italy, France, Norway, Spain) or milder country corporate governance codes which require reporting on recruitment efforts to achieve gender diversity (Austria, Denmark, Germany, Ireland, Netherlands, Poland) (Terjesen et al. 2015). 
Greater representation of women in top positions has been claimed to have a positive influence on firm performance. Nonetheless, empirical evidence on this relationship is rather mixed (Post and Byron 2015) and the association is mostly seen in countries and sectors with a higher proportion of women in the labour force, i.e., where women's knowledge, experience, and skills are better appreciated (Christiansen et al. 2016). There is firmer evidence that a higher proportion of women among directors has the potential to eradicate barriers to women's professional careers at lower levels. Greater presence of women in top management tends to co-exist with narrower gender gaps in promotion (Kunze and Miller 2017) and earnings (Cohen and Huffman 2007; Hultin and Szulkin 2003), though some studies yielded insignificant findings (Bertrand et al. 2019). Others showed that the relationship also depends on the sector (Magda and Cukrowska-Torzewska 2019), on whether the share of female directors is large enough to reach a 'critical mass' (Schwartz-Ziv 2017), and whether female managers are present among direct supervisors or at the top executive level (Cohen and Huffman 2007; Hultin and Szulkin 2003).

\subsection{Gender and Earnings}

The increase in women's labour market participation, employment, and working hours over the last decades has been accompanied by a rise in women's earnings and their gradual convergence towards the earnings of men. Yet, despite the closing of the gender pay gap, women continue to earn less, and the gap persists in numerous economies worldwide. The Organisation for Economic Co-operation and Development (OECD) data show that over the last four decades the gender pay gap, defined as the difference between the median earnings of men and women relative to the median earnings of men, decreased by around 20 per cent in Australia and Sweden, 30 per cent in Finland, 40 per cent in Japan, and to as much as 50-60 per cent in the US and the UK (OECD 2019b). The speed of convergence was larger in countries with higher initial earning inequality (Kunze 2018) and was strongly related to the increase in women's education (OECD 2017; Weichselbaumer and Winter-Ebmer 2005).

The size of the gender wage gap varies in many dimensions, including workers' education level, age, type of job performed, and position (Goldin 2014). Greater gaps are reported among better educated workers (OECD 2017) and at the top of the wage distribution (Arulampalam et al. 2007). The disparities between men's and women's earnings also tend to widen over the life cycle (Goldin 2014). They are generally smaller within jobs or at the firm level than at the country level, which reflects that part of the gender wage gap is due to the sorting of men to firms that pay on average more (Korkeamäki and Kyyrä 2006). However, the pay gap still exists within jobs, which as Goldin (2014) argues is largely due to the nonlinear relationship between earnings and work hours, and particularly disproportional rewards for long hours, typical of corporate, financial, and legal jobs. 


\section{SOURCES OF GENDER INEQUALITIES IN THE LABOUR MARKET}

\subsection{Education}

Education is a key determinant of labour market performance. In the mid-1980s men still dominated among university students in most of the OECD countries (Vincent-Lancrin 2008), which could partly explain the gender difference in labour market outcomes. The situation has, however, changed dramatically since then. By the end of the previous decade, there were more women than men among university students across the OECD except for Switzerland (De Hauw et al. 2017). In 2018, the proportion of women with tertiary education among 25-34 year olds in OECD countries reached 50 per cent whereas among men it was 38 per cent (OECD 2019c). Consequently, the gender gap in educational attainment can no longer explain the worse labour market outcomes of women.

Yet, what still remains largely unchanged are gender differences in the field of education (Barone 2011). Women to a higher extent than men choose to study arts and humanities, education, and health and welfare rather than science, technology, engineering and mathematics (STEM). In 2014, for instance, across the OECD countries women accounted for only 24 per cent of entrants into engineering, manufacturing, and construction and only 20 per cent into computer science programmes (OECD 2017).

There is firm evidence that the field of education is more important for explaining women's disadvantaged position in the labour market than educational attainment. According to Francesconi and Parey (2018), the field of study explains more than half of the gender gap in pay among university graduates in Germany; for the US, Brown and Corcoran (1997) found that the respective number is around one-quarter to one-half. Socialisation at the parental home appears to be the main reason for girls choosing arts and humanities rather than mathematics (Støren and Arnesen 2007), though the differences may also be driven by comparative advantages of either gender in a particular field of study (Jonsson 1999). In response to the latter argument, Fryer and Levitt (2010) found that there is no gender difference in math performance upon entry to school, but it evolves with time. The authors concluded that socialisation received at school may thus be critical for lower enrolment of girls into STEM. Women's lack of belief about succeeding in STEM along with certain characteristics of STEM jobs (e.g., long working hours outside the normal work schedule) that impact the work-family balance have been also claimed to stand behind the gender difference in the fields of study (European Commission 2018).

\subsection{Parenthood and Child-Related Career Breaks}

As in the case of field of study, childrearing obligations are one of the major reasons for women's poorer performance in the labour market. Across the developed countries, mothers allocate substantially more time to childcare than fathers, especially in the first few years after birth. This, in turn, has important consequences for women's careers. There is wide evidence that mothers are less often employed than childless women (Pettit and Hook 2005), have poorer promotion prospects (Correll et al. 2007; Heilman and Okimoto 2008), and tend to receive lower wages (Budig et al. 2012; Cukrowska-Torzewska and Matysiak 2020). 
There are numerous mechanisms through which having children affects women's work careers. First, career breaks and reduced working hours lead to deterioration of human capital. Some employers may also avoid promoting women who took a long parental leave as they may perceive them as unattached to work. Evertsson and Duvander (2011) found that mothers who stayed on leave for 16 months or more were less likely to experience an upward occupational mobility, and Puhani and Sonderhof (2011) reported that longer parental leave is negatively associated with women's chances to participate in employer-arranged training. Related to that, Evertsson (2016) found that leave taking after childbirth leads to women's lower wages and this penalty increases with leave duration and women's education. The penalty for taking parental leave was also found to be higher in male-dominated sectors which reward long working hours (Bertrand et al. 2010). Second, mothers display worse labour market outcomes because they choose jobs which are better compatible with childcare, but pay lower wages and offer fewer promotion prospects. While single studies do not ultimately point to this explanation, two meta-studies provide it with some legitimacy (Weichselbaumer and Winter-Ebmer 2005; Cukrowska-Torzewska and Matysiak 2020). Finally, having children may also affect mothers' productivity and thereby affect their labour market outcomes. In line with this hypothesis, Yu and Kuo (2017) found that wage gaps are particularly high in jobs, which require substantial time and energy investments; a condition which cannot be easily met by mothers who already face high work demands at home. An opposite conclusion was drawn by Kmec (2011) who found that mothers do not report lower work effort than childless women and men.

While childless women usually outperform women with children in the labour market, fathers earn higher wages and occupy higher positions than childless men. This phenomenon, called 'fatherhood premium', is attributed to a selection of highly successful men into parenthood, increased work effort of new fathers who may feel obliged to provide income to a larger family, and discriminatory practices of employers who perceive fathers as highly reliable and committed employees (Hodges and Budig 2010). So far, it is not clear which of these mechanisms is responsible for the fatherhood premium. Some studies showed that neither selection of highly successful men into parenthood nor higher work effort fully explain fatherhood premium (Baranowska-Rataj and Matysiak forthcoming; Hodges and Budig 2010) even though some men indeed tend to work longer hours after becoming fathers (Kaufman and Uhlenberg 2000). Finally, a corresponding study by Correll et al. (2007) revealed discriminatory practices against childless men by showing that fathers with identical job attributes are more often recommended for hiring and promotion and offered higher salaries. This finding was not confirmed by other studies of this type, however (e.g., Fernandez-Lozano et al. 2019; Heilman and Okimoto 2008).

Last but not least, it has been argued that differences in fathers' and mothers' labour market position will narrow as men increase their involvement in domestic work and childcare (Goldscheider et al. 2015). Research demonstrated that mothers are more likely to be employed full-time if their male partners are more involved in housework (Fanelli and Profeta 2019) or make use of flexible work arrangements (Langner 2018). At the same time, studies from the US showed that mothers are more likely to earn lower wages and opt out from the labour market if their husbands overwork (Cha 2010). An increase in men's involvement in the family does not only affect mothers' but also fathers' work careers. Studies showed that fathers experience wage penalties for taking parental leave or using flexible work arrange- 
ments and that these penalties can be even higher than among mothers (Evertsson 2016; Rudman and Mescher 2013).

\subsection{Noncognitive Skills}

Recently, social scientists have turned to searching for explanations for the persistence of gender gaps in labour market outcomes in the differences in noncognitive skills among women and men. Studies consistently report that women are more risk averse than men and are less willing to compete, especially with men (see literature reviews by Croson and Gneezy 2009 and Niederle 2016). Women are also, on average, more neurotic, agreeable, and conscientious (South et al. 2018), are better at recognising colours and hearing faint sounds, and have a better sense of touch, smell, and taste, but are more sensitive to noises and perform worse on spatial tasks (Cobb-Clark 2016).

Empirical evidence on the role of noncognitive skills for gender differences in labour market outcomes is to date rather scarce. The review by Bertrand (2011) suggests that women are more likely to commit errors in highly competitive environments (Ors et al. 2013) and are less likely to negotiate their starting salaries (Greig 2008). It is not fully clear, however, whether these findings are purely driven by biological factors or socialisation patterns (Bertrand 2011). Furthermore, studies find that noncognitive skills mostly influence occupational choices (Baker and Cornelson 2018; Cobb-Clark and Tan 2011), but their role for men's and women's wages is less clear (Blau and Kahn 2017). As argued by Cobb-Clark (2016), risk aversion or extroversion may be a disadvantage in some jobs, but an asset in others. Cobb-Clark and Tan (2011) showed that the gender wage gap continues to persist after accounting for gender differences in personality traits and locus of control, and Baker and Cornelson (2018) even report an increase in the gender wage gap after accounting for selection into occupations on the basis of sensory or motor abilities.

\subsection{Gender Discrimination}

Gender differences in labour market outcomes may also arise in the event of discrimination. Empirical research on this topic relies either on decomposition methods or experiments. Decomposition methods aim at assessing how much of the gender gaps can be assigned to observable differences between women and men and what portion remains unexplained and thus can be attributed to unmeasured factors such as discrimination (Blau and Kahn 2017). This approach may, however, overestimate or underestimate actual discrimination if women or men have some unmeasured skills which make them more productive. For this reason, in recent years more attention has been devoted to experimental research (for an overview see Bertrand and Duflo 2017). Neumark et al. (1996) were amongst the first to use a correspondence study to uncover discrimination in hiring practices in the US. They found that women are by 35 percentage points less likely to be invited to an interview and by 40 percentage points less likely to receive a job offer in high-price restaurants than men with similar job attributes. Similarly, Goldin and Rouse (2000) showed that the hiring rate of women in American orchestras has substantially increased after adopting 'blind' auditions, in which musicians perform behind the screen to conceal their gender. Studies from Australia and Sweden have, however, reported no traces of discrimination in hiring (Booth and Leigh 2010; Carlsson 2011). 
Research also investigated gender discrimination in pay. For instance, Moss-Racusin et al. (2012) showed that science faculty perceive male applicants as more competent and recommend them for a higher starting salary than female applicants. Correll et al. (2007) also reported discrimination, but based on parenthood status. The study showed that American mothers were recommended lower starting salary and were less likely to be promoted or recommended for management than non-mothers with the same characteristics. No similar pattern was, however, found in Spain (Fernandez-Lozano et al. 2019), which suggests that the degree of gender discrimination varies by institutional setting as well as occupations and industries.

\section{POLICIES}

Gender differences in labour market outcomes vary substantially across countries and this diversity is usually attributed to the variation in family and labour market policies. Highly accessible public childcare with long opening hours is probably one of the most efficient instruments supporting mothers' participation in the labour market (De Henau et al. 2011; Pettit and Hook 2005) and their relative pay (Budig et al. 2012, 2016). Not much is known, however, on whether an increase in the childcare quality would encourage an earlier labour market (re-)entry of new mothers.

When it comes to leave policies, empirical evidence suggests a non-linear relationship between leave duration and women's employment (Pettit and Hook 2005), earnings (Budig et al. 2012, 2016), or promotion (Evertsson and Duvander 2011). This evidence is largely consistent with theoretical predictions which presuppose that short leave should have a positive influence on mothers' employment as it allows for taking time off from work without terminating work contract and for arranging proper childcare before employment (re-)entry. Longer leave, in turn, may lead to depreciation of human capital. There is no consensus, however, on the optimal duration of the leave for women's employment prospects, which ranges from six months (Baker and Milligan 2008) to even two years (Budig et al. 2012, 2016). This variety of findings may be due to the fact that consequences of leave use may depend on childcare availability, labour market structures, or woman's job characteristics.

Increasingly, parental leave policies are directed not only at mothers but also at fathers through adoption of quotas and nontransferable individualised leave rights. In 2017, Swedish fathers, for instance, accounted for 45 per cent of parental leave recipients and made use of 29 per cent of total leave days taken (as compared with 14 per cent in 2000) (OECD Family Database). So far, there has been little research on employment consequences of the extension of parental leave rights to fathers. Existing research shows that fathers who made use of leave experienced substantial wage penalties (Evertsson 2016; Rege and Solli 2013). At the same time, Budig et al. (2016) demonstrated that gender wage gaps are smaller in countries which introduced incentives for fathers to make use of parental leaves.

In addition, employment policies may also affect men and women's labour market outcomes. The right to switch from full-time to part-time work helps women to continue working after entering motherhood, though it seems to be most helpful to low- and medium-educated women (Goldin 2014; Hegewisch and Gornick 2011). Flexible working hours and the possibility to work from home may also help to combine work and care (Kelly et al. 2014), although they may also lead to longer working hours and increase work-family conflict (Schieman et al. 
2009). Recently, more attention has also paid to working time regulations, which could help curtail overtime among men (Adler and Lenz 2016).

Finally, some studies looked at the role of whole policy packages with the idea that policies are more effective when they 'come in a bunch'. Consistent with this idea, studies showed that women living in countries where policies support mothers' employment are more likely to be employed, work longer hours, and are less likely to experience wage penalties (Baranowska-Rataj and Matysiak 2016; Cukrowska-Torzewska and Matysiak 2020). There is also evidence that policies interact with each other in creating conditions which are particularly supportive of mothers' labour market outcomes (Cukrowska-Torzewska 2017) and that they are more efficient in countries with higher acceptance of mothers' paid work (Budig et al. 2012).

\section{CONCLUSION AND SUGGESTIONS FOR FURTHER RESEARCH}

A substantial body of empirical research has been conducted in order to evaluate and explain gender differences in the labour market. The labour markets are dynamic, however, and they continuously pose new challenges to their participants and thus generate new research questions. One of these challenges is the rapid technological change (e.g., development of robots and information and communication technologies), which alters the ways people work and modifies the labour demand. The question of how technological advancement will change the relative position of female versus male workers remains unanswered and research on the topic is only beginning (e.g., Brussevich et al. 2019; Cook et al. 2018). Similarly, the ongoing population ageing, the inevitable switch to green energy and the Covid-19 pandemic will transform the conditions of participating in the labour market and also affect its gender dimension.

Furthermore, many of the questions on the relative position of women and men in the labour market that have already been posed continue to be unanswered. For example, we still do not know why women tend to choose certain fields of study (humanities, education, health and welfare) instead of maths, informatics, or engineering and why working in education or healthcare, which are both of high social importance, continues to be less valued in financial terms than working in typically male professions. Similarly, while research has shown that gender differences in noncognitive skills are partly responsible for the persistence of occupational segregation, it remains unclear whether and how these differences contribute to the emergence of vertical segregation and gender pay gaps. Women's underrepresentation at the executive level and its role for women's relative pay is another area that remains understudied.

More research is also needed on the role of the social context for shaping men's and women's labour market outcomes. So far, most of the researchers' attention has been paid to family policies and far less has been done on other aspects of the social context, including employment policies (e.g., flexible working hours, telework, working time regulations, antidiscriminatory laws), labour market structures (e.g., industry, sector, occupation, union density, wage distributions) and social norms about men's and women's roles. Equally important and poorly addressed are firm-level factors (e.g., company policies, norms, practices), peculiarities of certain jobs and occupations and family- and household-level factors (e.g., partners' involvement in the labour market and the family). 
Finally, progress is needed in terms of the methods and approaches used. First, research could provide us with more information on the changes in men and women's situations in the labour market even such research uses simple aggregate measures but applies a cohort approach. In that respect, sociologists and economists working in the field could learn from demographers who have long realised that aggregate measures may lead to distorted conclusions if successive cohorts shift the timing of events across the life course. More knowledge could also be gained from research focusing on individuals. Even though the shift from a cross-sectional to a longitudinal approach has already taken in individual-level research in the field, there is still room for investigating how the accumulation of various family-related events (such as union formation and dissolution, childbearing, or family migration) influence partners' work careers (taking the couple dynamics into account), and how they translate into gender differences in labour market later in life. Last but not least, more research employing experimental and quasi-experimental techniques could help us unravel causal relationships between the possible determinants and men and women's labour market outcomes, including employers' practices, policies, laws, structures, and social norms.

\section{ACKNOWLEDGEMENTS}

This chapter was prepared thanks to the funding of the Polish National Agency for Academic Exchange provided to Anna Matysiak and Ewa Cukrowska-Torzewska under the Polish Returns 2019 Programme.

\section{NOTE}

1. There is some dispute about the accuracy of this indicator. It is very sensitive to the level of detail of the data on occupations, i.e., whether data with two-, three-, or four-digit occupational coding are used.

\section{REFERENCES}

Adler, M.A. and K. Lenz (2016), 'Comparative father involvement: The dynamics of gender culture, policy and practice', in M.A. Adler and K. Lenz (eds), Father Involvement in the Early Years: An International Comparison of Policy and Practice, Chicago, IL: University of Chicago Press Books, pp. 231-52. doi:10.2307/j.ctt1t897nx.12.

Arulampalam, W., A.L. Booth, and M.L. Bryan (2007), 'Is there a glass ceiling over Europe? Exploring the gender pay gap across the wage distribution', ILR Review, 60 (2), 163-86. doi:10.1177/ 001979390706000201.

Baker, M. and K. Cornelson (2018), 'Gender-based occupational segregation and sex differences in sensory, motor, and spatial aptitudes', Demography, 55 (5), 1749-75. doi:10.1007/ s13524-018-0706-3.

Baker, M. and K. Milligan (2008), 'How does job-protected maternity leave affect mothers' employment?', Journal of Labor Economics, 26 (4), 655-91. doi:10.1086/591955.

Baranowska-Rataj, A. and A. Matysiak (2016), 'The causal effects of the number of children on female employment: Do European institutional and gender conditions matter?', Journal of Labor Research, 37 (3), 343-67. doi:10.1007/s12122-016-9231-6.

Baranowska-Rataj, A. and A. Matysiak (forthcoming), 'Family size and men's labor market outcomes: Do social beliefs about men's roles in the family matter?', Feminist Economics. 
Barone, C. (2011), 'Some things never change: Gender segregation in higher education across eight nations and three decades', Sociology of Education, 84 (2), 157-76. doi:10.1177/0038040711402099.

Bertrand, M. (2011), 'New perspectives on gender', in O. Ashenfelter and D. Card (eds), Handbook of Labor Economics, North-Holland: Elsevier, pp. 1543-90. doi:10.1016/S0169-7218(11)02415-4.

Bertrand, M. and E. Duflo (2017), 'Field experiments on discrimination', in A.V. Banerjee and E. Duflo (eds), Handbook of Economic Field Experiments, Vol. 1, North-Holland: Elsevier, pp. 309-93. doi: 10.1016/bs.hefe.2016.08.004.

Bertrand, M., C. Goldin, and L.F. Katz (2010), 'Dynamics of the gender gap for young professionals in the financial and corporate sectors', American Economic Journal: Applied Economics, 2 (3), 228-55. doi:10.1257/app.2.3.228.

Bertrand, M., S.E. Black, S. Jensen, and A. Lleras-Muney (2019), 'Breaking the glass ceiling? The effect of board quotas on female labour market outcomes in Norway', Review of Economic Studies, 86 (1), 191-239. doi:10.1093/restud/rdy032.

Bettio, F. (2002), 'The pros and cons of occupational gender segregation in Europe', Canadian Public Policy, 28, 65-84. doi:10.2307/3552344.

Bettio, F. and A. Verashchagina (2009), Gender Segregation in the Labour Market. Root Causes, Implications and Policy Responses in the EU, Luxembourg: European Commission, Directorate-General for Employment, Social Affairs and Equal Opportunities.

Bettio, F., M. Corsi, C. D'Ippoliti, A. Lyberaki, M. Samek Lodovici, and A. Verashchagina (2013), The Impact of the Economic Crisis on the Situation of Women and Men and on Gender Equality Policies, Luxembourg: Publications Office of the European Union.

Blau, F.D. and L.M. Kahn (2017), 'The gender wage gap: Extent, trends, and explanations', Journal of Economic Literature, 55 (3), 789-865. doi:10.1257/jel.20160995.

Blau, F.D., P. Brummund, and A.Y.-H. Liu (2013), 'Trends in occupational segregation by gender 1970-2009: Adjusting for the impact of changes in the occupational coding system', Demography, 50, 471-92. doi:10.1007/s13524-012-0151-7.

Booth, A. and A. Leigh (2010), 'Do employers discriminate by gender? A field experiment in female-dominated occupations', Economics Letters, 107 (2), 236-8. doi:10.1016/j.econlet.2010.01.034.

Brown, C. and M. Corcoran (1997), 'Sex-based differences in school content and the male-female wage gap', Journal of Labor Economics, 15 (3), 431-65. doi:10.1086/209867.

Brussevich, M., E. Dabla-Norris, and S. Khalid (2019), 'Is technology widening the gender gap? Automation and the future of female employment', IMF Working Papers, 19/91.

Budig, M.J., J. Misra, and I. Boeckmann (2012), 'The motherhood penalty in cross-national perspective: The importance of work-family policies and cultural attitudes', Social Politics: International Studies in Gender, State and Society, 19 (2), 163-93. doi:10.1093/sp/jxs006.

Budig, M.J., J. Misra, and I. Boeckmann (2016), 'Work-family policy trade-offs for mothers? Unpacking the cross-national variation in motherhood earnings penalties', Work and Occupations, 43 (2), 119-77. doi:10.1177/0730888415615385.

Carlsson, M. (2011), 'Does hiring discrimination cause gender segregation in the Swedish labor market?', Feminist Economics, 17 (3), 71-102. doi:10.1080/13545701.2011.580700.

Cha, Y. (2010), 'Reinforcing separate spheres: The effect of spousal overwork on men's and women's employment in dual-earner households', American Sociological Review, 75 (2), 303-29. doi:10.1177/ 0003122410365307.

Christiansen, L., L. Huidan, J. Pereira, P. Topalova, and R. Turk (2016), 'Gender diversity in senior positions and firm performance: Evidence from Europe', IMF Working Papers, 16/50.

Cobb-Clark, D.A. (2016), 'Biology and gender in the Labor Market', IZA Discussion Paper, 10386.

Cobb-Clark, D.A. and M. Tan (2011), 'Noncognitive skills, occupational attainment, and relative wages', Labour Economics, 18 (1), 1-13. doi:10.1016/j.labeco.2010.07.003.

Cohen, P.N. and M.L. Huffman (2007), 'Working for the woman? Female managers and the gender wage gap', American Sociological Review, 72 (5), 681-704. doi:10.1177/000312240707200502.

Cook, C., R. Diamond, J. Hall, J.A. List, and P. Oyer (2018), 'The gender earnings gap in the gig economy: Evidence from over a million rideshare drivers', National Bureau of Economic Research Working Paper Series, No. 24732.

Correll, S.J., S. Benard, and I. Paik (2007), 'Getting a job: Is there a motherhood penalty?', American Journal of Sociology, 112 (5), 1297-339. doi:10.1086/511799. 
Croson, R. and U. Gneezy (2009), 'Gender differences in preferences', Journal of Economic Literature, 47 (2), 448-74. doi:10.1257/jel.47.2.448.

Cukrowska-Torzewska, E. (2017), 'Cross-country evidence on motherhood employment and wage gaps: The role of work-family policies and their interaction', Social Politics, 24 (2), 178-220. doi:10.1093/ $\mathrm{sp} / \mathrm{j} \mathrm{xx} 004$.

Cukrowska-Torzewska, E. and A. Matysiak (2020), 'The motherhood wage penalty: A meta-analysis' Social Science Research, 88-9. doi:10.1016/j.ssresearch.2020.102416.

De Hauw, Y., A. Grow, and J. Van Bavel (2017), 'The reversed gender gap in education and assortative mating in Europe', European Journal of Population, 33 (4), 445-74. doi:10.1007/s10680-016-9407-z.

De Henau, J., D. Meulders, and S. O'Dorchai (2011), 'Maybe baby: Comparing partnered women's employment and child policies in the EU-15', Feminist Economics, 16 (1), 43-77. doi:10.1080/ 13545700903382703.

Duncan, O.D. and B. Duncan (1955), 'A methodological analysis of segregation indexes', American Sociological Review, 20 (2), 210-17. doi:10.2307/2088328.

European Commission (2018), Women in the Digital Age. doi:10.2759/526938.

Eurostat (2019a), 'Employment rates by sex, age and educational attainment (lfsa_ergaed)', accessed 22 November 2019 at https://appsso.eurostat.ec.europa.eu/nui/show.do?dataset=lfssa_ergaed\&lang=en.

Eurostat (2019b), 'Employment by sex, age, professional status and occupation (lfsa_egais)', accessed 13 June 2019 at https://appsso.eurostat.ec.europa.eu/nui/show.do?dataset=lfsa_egais\&lang=en.

Eurostat (2020a), 'Employment rates by sex, age and citizenship (lfsa_ergan)', accessed 28 May 2020 at https://appsso.eurostat.ec.europa.eu/nui/show.do?dataset=lfsa_ergan\&lang=en.

Eurostat (2020b), 'Average number of usual weekly hours of work in main job, by sex, professional status, full-time/part-time and economic activity (from 2008 onwards, NACE Rev. 2) (lfsa ewhun2)', accessed 28 May 2020 at https://appsso.eurostat.ec.europa.eu/nui/show.do?dataset=lfsa_ewhun2\& lang=en.

Evertsson, M. (2016), 'Parental leave and careers: Women's and men's wages after parental leave in Sweden', Advances in Life Course Research, 29, 26-40. doi:10.1016/j.alcr.2016.02.002.

Evertsson, M. and A.-Z. Duvander (2011), 'Parental leave. Possibility or trap? Does family leave length effect Swedish women's labour market opportunities?', European Sociological Review, 27 (4), 435-50. doi:10.1093/esr/jcq018.

Fanelli, E. and P. Profeta (2019), 'Fathers' involvement in the family, fertility and maternal employment: Evidence from Central and Eastern Europe', Dondena Working Paper, 131.

Fernandez-Lozano, I., M.J. González, T. Jurado-Guerrero, and J.-I. Martínez-Pastor (2019), 'The hidden cost of flexibility: A factorial survey experiment on job promotion', European Sociological Review, 36 (2), 265-83. doi:10.1093/esr/jcz059.

Francesconi, M. and M. Parey (2018), 'Early gender gaps among university graduates', European Economic Review, 109, 63-82. doi:10.1016/j.euroecorev.2018.02.004.

Fryer, R.G. and S.D. Levitt (2010), 'An empirical analysis of the gender gap in mathematics', American Economic Journal: Applied Economics, 2 (2), 210-40. doi:10.1257/app.2.2.210.

Goldin, C. (2014), 'A grand gender convergence: Its last chapter', American Economic Review, 104 (4), 1091-119. doi:10.1257/aer.104.4.1091.

Goldin, C. and C. Rouse (2000), 'Orchestrating impartiality: The impact of "blind" auditions on female musicians', American Economic Review, 90 (4), 715-41. doi:10.1257/aer.90.4.715.

Goldscheider, F., E. Bernhardt, and T. Lappegård (2015), 'The gender revolution: A framework for understanding changing family and demographic behavior', Population and Development Review, 41 (2), 207-39. doi:10.1111/j.1728-4457.2015.00045.x.

Greig, F. (2008), 'Propensity to negotiate and career advancement: Evidence from an investment bank that women are on a "slow elevator"', Negotiation Journal, 24 (4), 495-508. doi:10.1111/j.1571-9979 .2008.00200.x.

Hegewisch, A. and J.C. Gornick (2011), 'The impact of work-family policies on women's employment: A review of research from OECD countries', Community, Work and Family, 14 (2), 119-38. doi:10 $.1080 / 13668803.2011 .571395$.

Heilman, M.E. and T.G. Okimoto (2008), 'Motherhood: A potential source of bias in employment decisions', Journal of Applied Psychology, 93 (1), 189-98. doi:10.1037/0021-9010.93.1.189. 
Hobson, B., S. Fahlen, and J. Takacs (2011), 'Agency and capabilities to achieve a work-life calance: A comparison of Sweden and Hungary', Social Politics, 18 (2), 168-98. doi:10.1093/sp/jxr007.

Hodges, M.J. and M.J. Budig (2010), 'Who gets the baby bonus? Organizational hegemonic masculinity and the impact of fatherhood on earnings', Gender and Society, 24 (6), 717-45. doi:10.1177/ 0891243210386729.

Hultin, M. and R. Szulkin (2003), 'Mechanisms of inequality: Unequal access to organizational power and the gender wage gap', European Sociological Review, 19 (2), 143-59. doi:10.1093/esr/19.2.143.

ILO (2019), The Business Case for Change, Geneva: International Labour Office.

Jonsson, J.O. (1999), 'Explaining sex differences in educational choice: An empirical assessment of a rational choice model', European Sociological Review, 15 (4), 391-404. doi:10.1093/oxfordjournals .esr.a018272.

Kanjuo-Mrčela, A. and N. Cernigoj Sadar (2011), 'Social policies related to parenthood and capabilities of Slovenian parents', Social Politics: International Studies in Gender, State and Society, 18 (2), 199-231. doi:10.1093/sp/jxr010.

Kaufman, G. and P. Uhlenberg (2000), 'The influence of parenthood on the work effort of married men and women', Social Forces, 78 (3), 931-47. doi:10.2307/3005936.

Kelly, E.L., P. Moen, J.M. Oakes, W. Fan, C. Okechukwu, K.D. Davis, L.B. Hammer, E. Ernst Kossek, R. Berkowitz King, G.C. Hanson, F. Mierzwa, and L.M. Casper (2014), 'Changing work and workfamily conflict: Evidence from the work, family, and health network', American Sociological Review, 79 (3), 485-516. doi:10.1177/0003122414531435.

Kmec, J.A. (2011), 'Are motherhood penalties and fatherhood bonuses warranted? Comparing pro-work behaviors and conditions of mothers, fathers, and non-parents', Social Science Research, 40 (2), 444-59. doi:10.1016/j.ssresearch.2010.11.006.

Korkeamäki, O. and T. Kyyrä (2006), 'A gender wage gap decomposition for matched employeremployee data', Labour Economics, 13 (5), 611-38. doi:10.1016/j.labeco.2005.02.001.

Kunze, A. (2018), 'The gender wage gap in developed countries', in S.L. Averett, L.M. Argys, and S.D. Hoffman (eds), The Oxford Handbook of Women and the Economy, Oxford: Oxford University Press. doi:10.1093/oxfordhb/9780190628963.013.11.

Kunze, A. and A.R. Miller (2017), 'Women helping women? Evidence from private sector data on workplace hierarchies', Review of Economics and Statistics, 99 (5), 769-75. doi:10.1162/REST_a_00668.

Langner, L.A. (2018), 'Flexible men and successful women: The effects of flexible working hours on German couples' wages', Work, Employment and Society, 32 (4), 687-706. doi:10.1177/ 0950017017708161.

Magda, I. and E. Cukrowska-Torzewska (2019), 'Do women managers lower gender pay gaps? Evidence from public and private firms', Feminist Economics, 25 (4), 185-210. doi:10.1080/13545701.2019 .1634828 .

Moss-Racusin, C.A., J.F Dovidio, V.L. Brescoll, M.J. Graham, and J. Handelsman (2012), 'Science faculty's subtle gender biases favor male students', Proceedings of the National Academy of Sciences, 109 (41), 16474-9. doi:10.1073/pnas.1211286109.

Mutari, E. and D.M. Figart (2001), 'Europe at a crossroads: Harmonization, liberalization, and the gender of work time', Social Politics: International Studies in Gender, State and Society, 8 (1), 36-64. doi: 10.1093/sp/8.1.36.

Neumark, D., R.J. Bank, and K.D. Van Nort (1996), 'Sex discrimination in restaurant hiring: An audit study', Quarterly Journal of Economics, 111 (3), 915-41. doi:10.2307/2946676.

Niederle, M. (2016), 'Gender', in J. Kagel and A.E. Roth (eds), Handbook of Experimental Economics, Vol. 2, Princeton, NJ: Princeton University Press, pp. 481-553. doi:10.1515/9781400883172-009.

OECD (2017), The Pursuit of Gender Equality: An Uphill Battle, Paris: OECD Publishing. doi:10.1787/ 9789264281318-en.

OECD (2019a), 'OECD employment database. LFS by sex and age - indicators', accessed 2 December 2019 at https://stats.oecd.org/Index.aspx?QueryId=64196.

OECD (2019b), 'OECD employment database. Decile ratios of gross earnings: Gender wage gap (median)', accessed 8 November 2019 at https://stats.oecd.org/index.aspx?queryid $=64160 \#$.

OECD (2019c), Education at a Glance 2019, Paris: OECD Publishing. doi:10.1787/f8d7880d-en.

Ors, E., F. Palomino, and E. Peyrache (2013), 'Performance gender gap: Does competition matter?', Journal of Labor Economics, 31 (3), 443-99. doi:10.1086/669331. 
Pettit, B. and J.L. Hook (2005), 'The structure of women's employment in comparative perspective', Social Forces, 84 (2), 779-801. doi:10.1353/sof.2006.0029.

Post, C. and K. Byron (2015), 'Women on boards and firm financial performance: A meta-analysis', Academy of Management Journal, 58 (5), 1546-71. doi:10.5465/amj.2013.0319.

Puhani, P.A. and K. Sonderhof (2011), 'The effects of parental leave extension on training for young women', Journal of Population Economics, 24 (2), 731-60. doi:10.1007/s00148-009-0295-y.

Rege, M. and I.F. Solli (2013), 'The impact of paternity leave on fathers' future earnings', Demography, 50 (6), 2255-77. doi:10.1007/s13524-013-0233-1.

Rudman, L.A. and K. Mescher (2013), 'Penalizing men who request a family leave: Is flexibility stigma a femininity stigma?', Journal of Social Issues, 69 (2), 322-40. doi:10.1111/josi.12017.

Schieman, S., P. Glavin, and M.A. Milkie (2009), 'When work interferes with life: Work-nonwork interference and the influence of work-related demands and resources', American Sociological Review, 74 (6), 966-88. doi:10.1177/000312240907400606.

Schwartz-Ziv, M. (2017), 'Gender and board activeness: The role of a critical mass', Journal of Financial and Quantitative Analysis, 52 (2), 751-80. doi:10.1017/S0022109017000059.

South, S.C., A.M. Jarnecke, and C.E. Vize (2018), 'Sex differences in the big five model personality traits: A behavior genetics exploration', Journal of Research in Personality, 74, 158-65. doi:10.1016/ j.jrp.2018.03.002.

Støren, L.A. and C.Å. Arnesen (2007), ‘Women's and men's choice of higher education: What explains the persistent sex segregation in Norway?', Studies in Higher Education, 32 (2), 253-75. doi:10.1080/ 03075070701267293.

Terjesen, S., R.V. Aguilera, and R. Lorenz (2015), 'Legislating a woman's seat on the board: Institutional factors driving gender quotas for boards of directors', Journal of Business Ethics, 128 (2), 233-51. doi:10.1007/s10551-014-2083-1.

Vincent-Lancrin, S. (2008), 'The reversal of gender inequalities in higher education: An ongoing trend', Higher Education to 2030, Volume 1: Demography, Paris: OECD Publishing, pp. 265-98. doi:10 $.1787 / 9789264040663-11$-en.

Weichselbaumer, D. and R. Winter-Ebmer (2005), 'A meta-analysis of the international gender gap', Journal of Economics Survey, 19 (3), 479-511. doi:10.1111/j.0950-0804.2005.00256.x.

$\mathrm{Yu}, \mathrm{W}$. and J.C.-L. Kuo (2017), 'The motherhood wage penalty by work conditions: How do occupational characteristics hinder or empower mothers?', American Sociological Review, 82 (4), 744-69. doi:10.1177/0003122417712729. 